IRA-International Journal of Education \& Multidisciplinary Studies

ISSN 2455-2526; Vol.12, Issue 01 (July, 2018)

Pg. no. 1-22.

Institute of Research Advances

http://research-advances.org/index.php/IJEMS

\title{
Assessment of Nature Tourism Potential, in Rural Development in West Wollega Zone in The Case of Sayo Nole and Nole Kaba Districts, Ethiopia
}

Temesgen Soressa

Lecturer in Wollega University College of Social Science Department of Geography and Environmental Studies, Ethiopia.

Type of Review: Peer Reviewed.

DOI: http://dx.doi.org/10.21013/jems.v12.n1.p1

How to cite this paper:

Soressa, T. (2018). Assessment of Nature Tourism Potential, in Rural Development in West Wollega Zone in The Case of Sayo Nole and Nole Kaba Districts, Ethiopia. IRA International Journal of Education and Multidisciplinary Studies (ISSN 2455-2526), 12(1), 1-22.doi: http://dx.doi.org/10.21013/jems.v12.n1.p1

(C) Institute of Research Advances.

\section{(cc) EY-NO}

This work is licensed under a Creative Commons Attribution-Non Commercial 4.0 International License subject to proper citation to the publication source of the work.

Disclaimer: The scholarly papers as reviewed and published by the Institute of Research Advances (IRA) are the views and opinions of their respective authors and are not the views or opinions of the IRA. The IRA disclaims of any harm or loss caused due to the published content to any party.

Institute of Research Advances is an institutional publisher member of Publishers Inter Linking Association Inc. (PILA-CrossRef), USA. The institute is an institutional signatory to the Budapest Open Access Initiative, Hungary advocating the open access of scientific and scholarly knowledge. The Institute is a registered content provider under Open Access Initiative Protocol for Metadata Harvesting (OAI-PMH).

The journal is indexed \& included in WorldCat Discovery Service (USA), CrossRef Metadata Search (USA), WorldCat (USA), OCLC (USA), Open J-Gate (India), EZB (Germany) Scilit (Switzerland), Airiti (China), Bielefeld Academic Search Engine (BASE) of Bielefeld University, Germany, PKP Index of Simon Fraser University, Canada. 


\subsection{Introduction}

Tourism is not just the temporary movement of people to destinations outside their normal places. Tourism includes many geographic, economic, environmental, social, cultural and political dimensions. A tourism industry has a strong relationship with those dimensions because of its dependency and impact on it, and the interests of its stakeholders (Kauffmann 2008).

As stated by Sinha (2007) the study of tourism is the study of people away from their usual habitat of the establishments which responds to the requirement of travelers and the impact of that they have on the economic physical and social well-being of their hosts. Tourism is an attractive tool for economic development, specifically in the developing world. Viewed as an export industry of three Gs -- "get them in, get their Money, and get them out" tourism has assisted many developing countries to move away from a dependency on agriculture and manufacturing (Tooman, 1997.

Chosen forits ability to bring in needed foreign exchange earnings, income and employment, tourism has become a popular addition to economic development policies in many African, Asian, South and Central American countries. Although tourism seems to beading substantially to the economic growth of many of these regions, many developing countries are not reaping full benefits from tourism (Vaugeois, 1990).

Tourism in Ethiopia dates back to the pre-Axumite period when the first illustrated travel guides to Ethiopia can be found in the friezes of the pyramids and ancient sites of Egypt. These depicted travels to the land of Punt, which the Egyptians knew was the source of the Nile, and where they traded for gold, incense, ivory and slaves. The fourth century Persian historian Mani described the Kingdom of Axum as being one of the four great empires of the world, ranking it alongside China, Persia and Rome (World Bank, 2006). Modern tourism in Ethiopia can be said to have started with the formation of a government body to develop and control it in 1961: The Ethiopian Tourist Organization (Y.Mulualem, 2010).

\subsection{Statement of the Problem}

Developing countries that are endowed with abundant tourist attractions fail to capitalize on those resources in order to improve their export earnings capabilities. Lack of strategic objectives has been a drawback in some countries. Others suffer from negative perceptions of their destinations due mainly to unstable political situations, lack of security or poor facilities (N.Vaugeois, 1990)

Tourism is the largest industry in the world. The 800 million arrivals recorded for 2005 represented a 5.2\% growth rate from 2004 and an estimated value of US\$ 655 billion in worldwide tourism receipts and it is a large global industry that is expanding rapidly in developing countries (World Bank, 2006)

Tourism has become a phenomenon in both developed and developing economies across the globe, owing partly to bizarre of income generation, employment creation and poverty elimination potentials; and exploring development variables associated with the intangible products (Andriotis et al., 2008).

Ethiopia is among the world's least developed countries, this indicates that there is poverty prevalence in the population. Therefore, in this context, establishing and measuring links between tourism activity and poverty reduction is a critical rationale for considering public investment in the sector; some of these linkages are explored in economic assessment.

The case for tourism development as a way of bringing about economic development in a region or country has usually been made with a focus on economic modernization and economic growth. The assumption has been that any tourism development will eventually benefit the poor through trickle-down effects.

Therefore, there was research gap for economic development of tourism in a western part of the country, particularly in the study area. In line with the above problems, assessing tourism potential, constraints and future prospects in SayyoNole and NoleKaba districts was a very crucial issue for economic development in the study area. This because the area is endowed with different tourist attraction sites such as cultural religious site (DilaKobiworke), natural forest and mountain (like Jorgo forest and mountains, Dale Sayyo forest, Walaje Waterfall, and a chain of 
hills or GaaraTorbaatama) site, and manmade attraction (JorgoDagago burial monument sits and Dardara spring) places.

Even though there was a high potential of tourism site in the region, the sector has a little contribution to the local economic development as well as for the government revenue. Generally, the researcher observed these problems in the study area and this research identified potential and cause and consequences of tourism development.

\subsection{Objective}

The aim of this study was to develop scenarios and suggestion for a solution based on the analysis of potential of the tourism site in contributing to economic development of the districts.

\subsection{Material and Methods}

\subsubsection{Sources and methods of data collection}

In order to achieve the objectives of the study which are stated above, and to address research problem, both primary and secondary data sources were used. Different data collection instrumentsused to collect data from both primary and secondary sources. Among these; formal questionnaires for conveniently selected people surrounding the tourism site and, informal interviews and observation have been used. In order to have reliable data concerning tourism potential and constraints survey conducted through informal interviews were with municipal and Kebele officials.

Secondary data were obtained from different sources among these, the published and unpublished materials of government and nongovernmental organizations were the major sources of such information.

\subsubsection{Sampling technique}

There are verities of natural and cultural attraction potentials in 19 districts of west Wollega Zone. But there was no much emphasis has been given to those attraction sites as the base of cultural social and economic development. Identification of tourism potential is not an easy tax in the context of national regional and local level. To do so the researcher select two districts of 19 districts of west Wollega zone purposefully based on the officialdata,thesedistricts are endowedwith natural and cultural sites than any other. The target population was selected through purposive sampling method due to disperse of the population from the potential sits. Accordingly, to have relevant information about the potential sites 60 sample population were taken from tourism sector office of the districts and local elders living around the tourism potential sites.

\subsubsection{The survey mechanism}

The survey was conducted by employing local assistants and by the researcher. Extracaresweretaken to collect reliable and valid data.

\subsubsection{Method of data organization and analysis}

The data that were obtained from different sources like primary and secondary source were organized into tables, figures, and maps. The nature of this study was largely qualitative and also quantitative approach was used. Qualitative research is a multi-method focus involving an interpretive, naturalistic approach to its subject matter. This means that qualitative researchers study things in their natural setting, attempting to make sense of, or interpret phenomena in terms of the meanings people bring to them. Qualitative research involves the studied use and collection of a variety of empirical materials (Denzin\& Lincoln in Riley \&Love,2000).

Quantitative method was used for geo-statistical dates for the purpose of mapping sites and calculating areal coverage as well as for some socio-economic data of the target surrounding population 


\subsection{The significance of research}

Reliable information on potential and constraints of tourism in the study area is very important in planning economic development because the sector positively reacts to the issues of job opportunity, urbanization process, poverty alleviation, and source of revenue. Tourists were identified as a key factor in developing tourism in local communities. Therefore, the assessment of the present status of tourism which has positive implication in enhancing economic development is the central focus of this research. This study will contribute knowledge in the area of tourism and serves as an input for policy formulation as well as the research viewed into the challenges and earnest solution or recommendation.

\subsection{Framework on Potential Analysis of Tourism}

Figure 1. Framework of Potential Analysis of Tourism
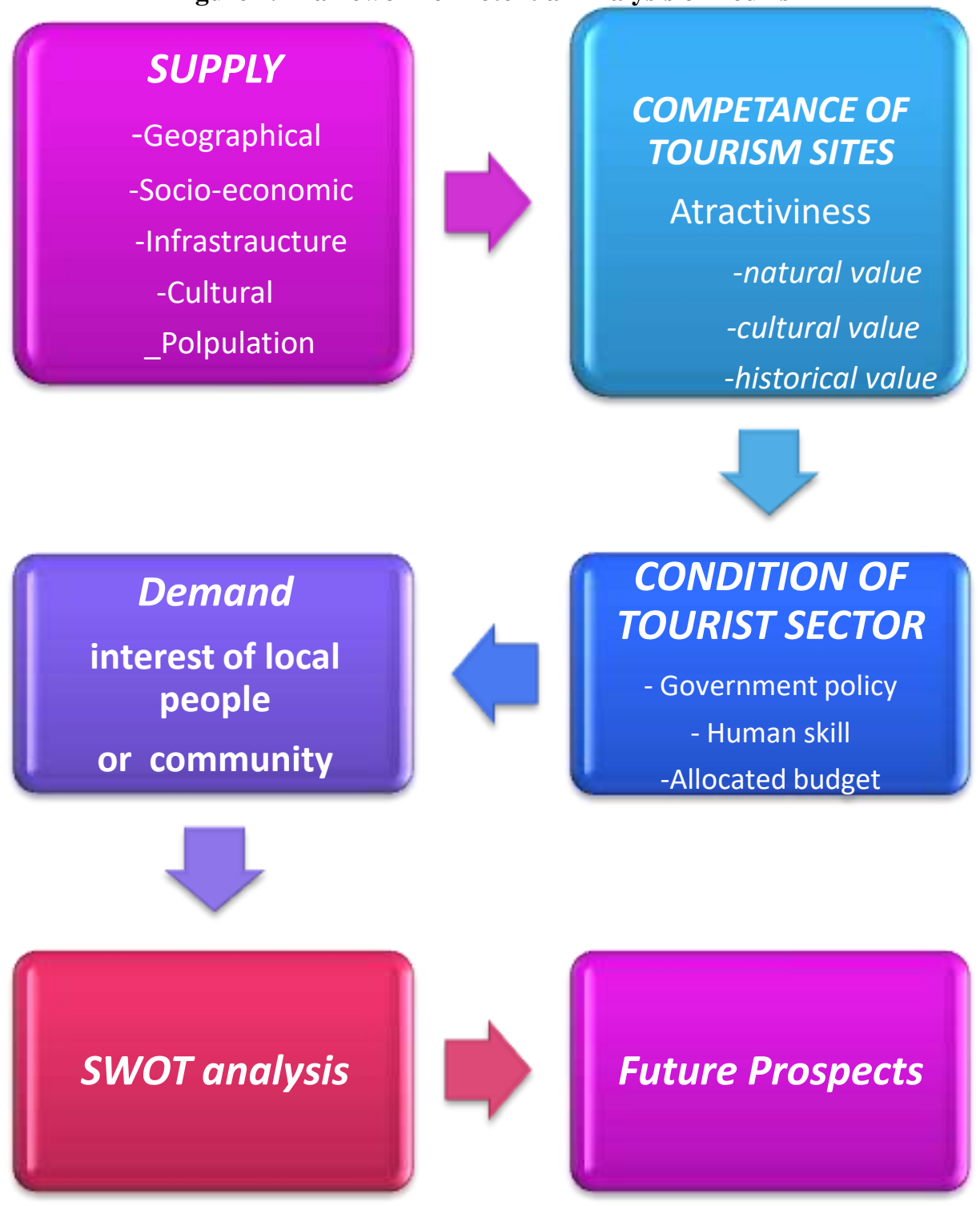

Source; developed by Author 2017 
Rural tourism potential depends on many factors analysis which has strong relationships with each other. These considered being the main process to identify the potential challenges and future prospects of tourism at the study area. these analyses were depending on 1) supply which includes, geographical situation socio-economic condition, infrastructure, culture and population aspects. 2) competence of tourism site, level of attractiveness and its uniqueness to attract tourists to the area 3) demands of the local people and tourism sector to develop the area as tourism site 4) condition of tourism sector which includes, government policy strategies and programs, human skill employed within the sector 5) strength and weakness of overall activities and the attraction sites 6) future prospects to understand the development of tourism. Therefore, the above diagram shows that these process as framework of the process

\section{REVIEW OF RELATED LITERATURE}

\subsection{Definition and concepts}

According to (Robert Christie Mill 2010), a variety of definitions exist for what we call tourism. Thus, it is important to know exactly what we are talking about when we say "tourism" for several reasons. The development of attractions and facilities requires increasingly large amounts of money. A decision to build or not build depends upon numbers of potential users. Is there a large enough market to support such a project, be it a hotel, restaurant or theme park? If we can arrive at a common definition of tourism, travel and tourist then we are better able to use the numbers or data to determine whether or not to build, where to advertise, which destinations are growing or fading. In short, our business decisions will be better if they are made with a full understanding of what exactly we are talking about.

Tourism comprises the activities of persons traveling to and staying in places outside their usual environment for not more than one consecutive year for leisure, business and other purposes not related to the exercise of an activity remunerated from within the place visited. (Malta Tourism Digest www.mtadigest.com.mt world tourism organization, 2012)

Tourism is the temporary short movement of people to the destinations outside the place where they normally live and work, and activities during their stay at those destinations; it includes movement for all purpose, as well as day visits and excursion (ICLRT, 1981)

Tourism is the set of activities of a person traveling to a place outside his or her usual environment for less than a year and whose main purpose of travel is other than the exercise of an activity remunerated from within the place visited (eolss.net/Sample-Chapters/C16/E1-48-50.pdf, accessed in 2017)

\subsection{World Tourism}

As stated by (ETTE 2003) sited in Meseret Getahun (2011), tourism is one of the fastest growing industries in the world. Recent studies indicate that nearly millions of tourists have traveled around the world and the countries they visited have earned billions of dollars from the money they spent. The sector became highly promising as the number of tourists is expected to increase significantly and generating trillions of dollars annually in the fore coming years. (ETTE, 2003)

Europe and Asia and the Pacific both were the fastest-growing regions (6 Percent) in terms of tourist arrivals in 2011. Popular uprisings in North Africa and the Middle East during 2011 took a toll on tourism in both regions: Africa recorded 1 percent increase, only, due to the loss of visitors in North Africa, while the Middle East saw an 8 percent decline in arrivals, (UNWTO, 2012) 
Table 2.1 International Tourism Arrival And Its Change

\begin{tabular}{|c|c|c|c|c|c|c|c|c|c|}
\hline \multirow[t]{2}{*}{ REGIONS } & \multicolumn{5}{|c|}{$\begin{array}{l}\text { INTERNATIONAL TOURIST } \\
\text { ARRIVAL }\end{array}$} & \multicolumn{3}{|c|}{ \% CHANGES } & \multirow{2}{*}{$\begin{array}{l}\text { Average } \\
\text { annual } \\
\text { growth } \\
(2009-2012 \\
\end{array}$} \\
\hline & 2008 & 2009 & 2010 & 2011 & 2012 & $09 / 08$ & $10 / 09$ & $12 / 11$ & \\
\hline EUROPE & 485.2 & 461.7 & 487.6 & 517.8 & -4.8 & 5.6 & 6.1 & 3.3 & 3.4 \\
\hline AMERICAS & 147.8 & 141.7 & 150.3 & 156.13 & 162.1 & 6.1 & 4.0 & 4.0 & 2.5 \\
\hline $\begin{array}{l}\text { ASIA \& THE } \\
\text { PACIFIC }\end{array}$ & 184.1 & 181.1 & 205.1 & 218.1 & 232.9 & 13.2 & 6.3 & 7.0 & 6.2 \\
\hline MIDDLE EAST & 55.2 & 52.8 & 59.2 & 55.13 & 52.6 & 1.1 & -7.0 & -4.6 & -3.6 \\
\hline AFRICA & 44.4 & 45.9 & 49.8 & 49.2 & 52.3 & 8.5 & -1.2 & 6.3 & 5.5 \\
\hline WORLD & 917 & 952 & 952 & 996 & 1035 & 7.8 & 4.6 & 4.0 & 3.2 \\
\hline
\end{tabular}

Source (UNWTO, 2012)

Travel \& Tourism is a key sector for economic development and job creation throughout the world. In 2016, Travel \& Tourism directly contributed US $\$ 2.3$ trillion and 109 million jobs worldwide. Taking its wider indirect and induced impacts into account, the sector contributed US\$7.6 trillion to the global economy and supported 292 million jobs in 2016. This was equal to $10.2 \%$ of the world's GDP, and approximately 1 in 10 of all jobs (WTTC, 2017).

\subsection{Tourism attraction Regions of the world}

The vast majority of domestic tourism occurs in developed countries. Europe accounts for over half of all domestic tourism while tourism to the Americas (North America, Central and South America and the Caribbean) adds an additional 37 percent; East Asia, and the Pacific contribute less than 10 per cent of the total; Africa, the Middle East, and South Asia combined only have 2 percent. The same situation is true when international travel is considered. Europe receives over two-thirds of all international arrivals and well over half of all receipts (R.C.Mill, 2010).

As it stated in The World Tourism Organization reports the following ten destinations as the most visited in terms of the number of international travelers in 2016.

Table 2.2 International Tourism Arrival by Region In 2016

\begin{tabular}{|c|l|c|c|}
\hline Rank & \multicolumn{1}{|c|}{ Country } & $\begin{array}{c}\text { UNWTO } \\
\text { Region }\end{array}$ & $\begin{array}{l}\text { International tourist } \\
\text { arrivals (2016) }\end{array}$ \\
\hline 1 & France & Europe & 86.2 million \\
\hline 2 & United States & North America & 80.3 million \\
\hline 3 & Spain & Europe & 75.6 million \\
\hline 4 & China & Asia & 59.3 million \\
\hline 5 & Italy & Europe & 52.5 million \\
\hline 6 & United Kingdom & Europe & 35.8 million \\
\hline 7 & Germany & Europe & 35.6 million \\
\hline
\end{tabular}




\begin{tabular}{|c|l|c|c|}
\hline Rank & \multicolumn{1}{|c|}{ Country } & $\begin{array}{c}\text { UNWTO } \\
\text { Region }\end{array}$ & $\begin{array}{l}\text { International tourist } \\
\text { arrivals (2016) }\end{array}$ \\
\hline 8 & Mexico & North America & 35.0 million \\
\hline 9 & Thailand & Asia & 32.6 million \\
\hline 10 & Turkey & Europe & 32.0 million \\
\hline
\end{tabular}

Source; WTO, 2016

\subsection{Tourism in east Africa}

Tourism is the fastest developing enterprise in Africa and currently one of the continent's major investment opportunities, viewing its $6 \%$ growth rate for the last decennium. Africa receives $4.8 \%$ of all tourist arrivals in the world, and 3.3\% of the receipts and although it is not at the heart of the global tourist market, this modest proportion of the world's number one industry is still important for the continent (ASC Info sheet 3 / 2008).

Kenya, Uganda, and Tanzania offer essentially the same type of tourist attractions. Of the three, tourism is most widely developed in Kenya. Over 40 percent of the tourists to Kenya come from Europe, principally the United Kingdom, West Germany, Switzerland and Italy. The United States accounts for about 10 percent of the visitors to Kenya. They come to visit the game parks, the wildlife reserves and the coast. (A. Kauffmann 2008)

The levels and types of tourism activity in the participating Central and East African countries differ markedly from country to country. This has a significant bearing on the type and level of investment opportunities in each country. The tourism industry in Comoros, Djibouti, Kenya, Mauritius, Madagascar, Seychelles, Tanzania, and Uganda is characterized by high levels of holiday compared with business tourism. In Burundi, Eritrea, Ethiopia, and Rwanda business and holiday tourism are equally important, while Somalia and Sudan have minimal holiday tourism at present (Profit, 2012)

\subsection{Tourism in Ethiopia}

As stated by World Bank (2006) cited in (A. Kauffmann, 2008), the Ethiopian tourism industry can be roughly divided into three important tourist zones. Firstly, the historic northern route. Secondly, the far south where pastoralist communities form tourist attractions. Finally, Addis Ababa, the capital, providing qualified tourism services and the central place for international arrival and departure. Ethiopia's principal driver for tourism is the rich culture and history.

The role of the tourism industry in Ethiopia's socio-economic development has always been recognized in the country. Noticeably, the number of international tourist arrivals has grown in leaps and bounds since the national development plan in 1965 in which the importance of the tourism industry in economic growth and development was highlighted leading to an average of 63,833 arrivals by the early 1970s. The ensuing period thereafter, however, could be described as the dark era for the tourism industry as captured in this excerpt drawn from the national tourism policy (UNECA, 2005) 
Figure 2 Income Distribution of Tourism from 2004-2024

\section{Constant 2013 ETBm}

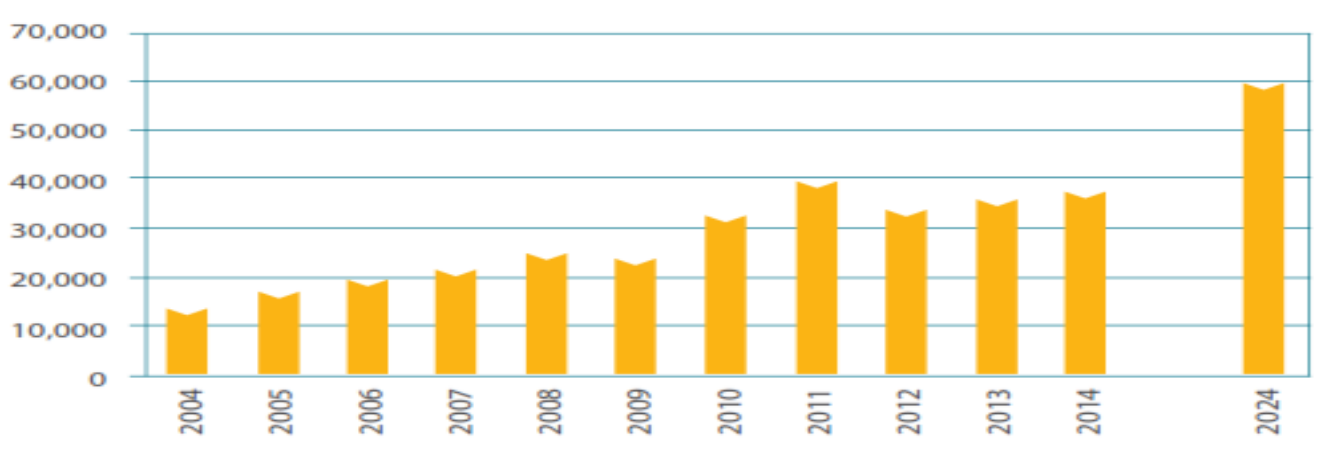

Source UNECA, 2005

Tourist destinations include Ethiopia's collection of national parks (including the Semien Mountains National Park), and historic sites, such as the cities of Axum, Negash Mosque, Sof 'UmerWasha, HararJugol and Lalibela. Developed in the 1960s, tourism declined greatly during the later 1970s and the 1980s under the Dergue. Recovery began in the 1990s, but growth has been constrained by the lack of suitable hotels and other infrastructure, despite a boom in construction of small and medium-sized hotels and restaurants. (Wikipedia the free encyclopedia, 2009)

Kauffmann (2008) suggested that Nature tourism can be identified as the third segment of Ethiopia's tourism market after culture and history tourism. Since the majority of the tourists are coming for historical, and cultural attractions in Ethiopia, natural attractions of the CRV could enforce this third segment. Ethiopia has experience in nature tourism, but has strong competition on this from neighboring countries like Kenya, and Tanzania. Cultural and historical tourism are the focal points of the Ethiopian tourism industry, but nature tourism can become one of the components of the tourism industry

\subsubsection{Most visited sites of Ethiopian tourism}

Ethiopia has a diversity of natural and human created-tourism potential sites. Therefore, Ethiopia's uniqueness makes it a fascinating destination for every kind of traveller, but in particular for the traveler who wants that bit more. North Ethiopia's historic sites are extremely wide-ranging and possibly the most extensive in the whole of Sub-Saharan Africa. Mostly visited areas of Ethiopia were the Simien Mountain National Park (North Gondar Zone), the rock-hewn churches of Lalibela (North WolloZone) Awash Lower Valley palaeontological and prehistoric Sites,Axum historical and archaeological sites, central Tigray (Tigray Region), Valley of the Omo, palaeontological and prehistoric sites (South Omo zone), Tiya pre-historical and archaeological sites and central Tigray (Tigray region). 
Figure 3. Tourism Region of Ethiopia Map

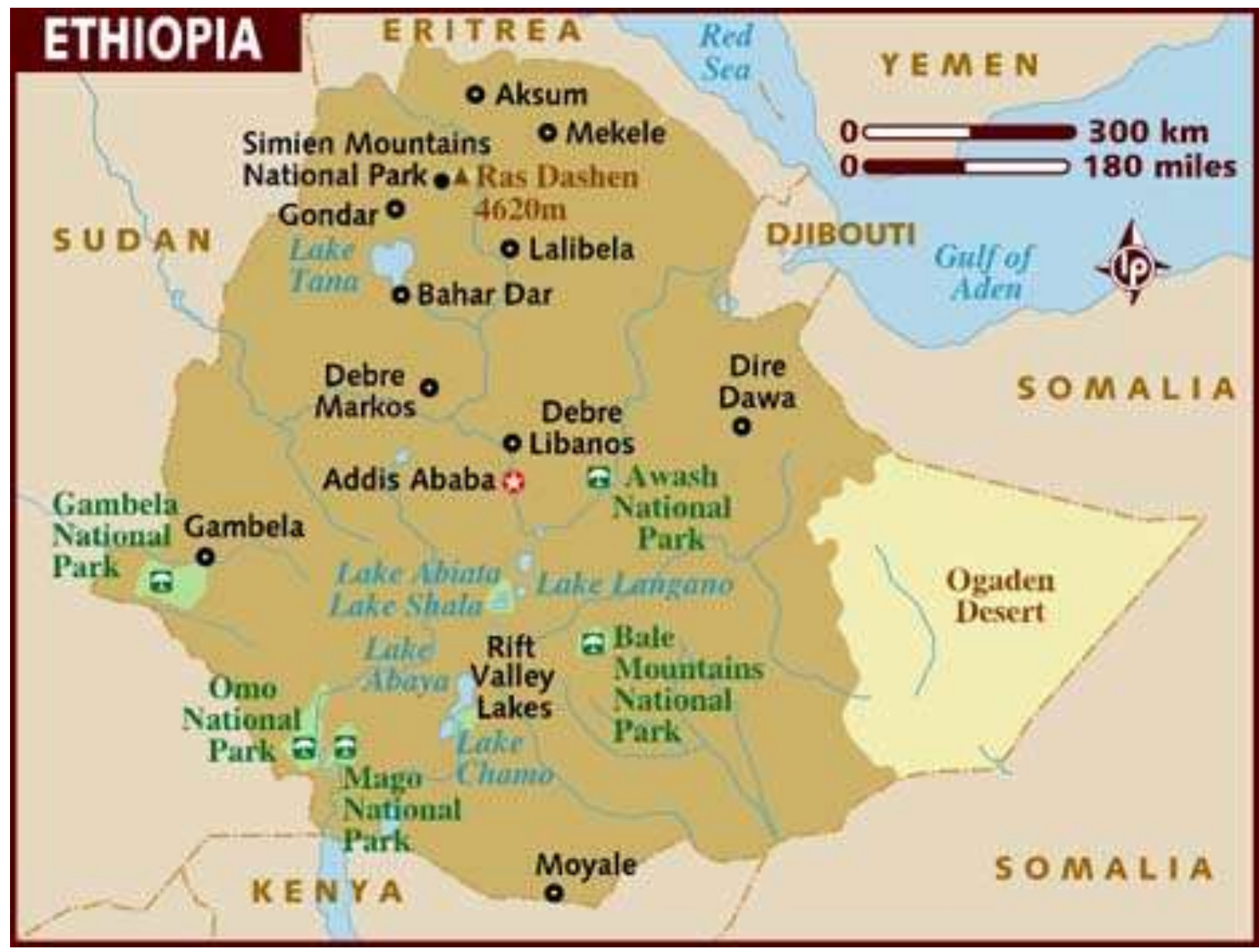

Source; Ethiopian treasure. http://www.ethiopiantreasures.co.uk/pages/geography.htm,acessed in 2017 .

\subsection{Rural Tourism}

Rural tourism as a kind of tourism, which facilitates the permanent residence of tourists in rural areas for the purpose of vacationing and/or involvement with agricultural activities. Rural tourist product may be developed in two ways: through the "traditional" rural tourism (farm accommodation, agricultural activities, etc.) and other "alternative" types of rural recreation (environmental, ethnographical, cultural, etc.). The way of development determines the set of approaches to the organization of rural tourism in a particular rural community. (A. Trukhachev 2015)

Rural tourism focuses on actively participating in a rural lifestyle. It can be a variant of ecotourism. Many rural villages can facilitate tourism because many villagers are hospitable and eager to welcome (and sometimes even host) visitors. Agriculture is becoming highly mechanized and therefore, requires less manual labor. This trend is causing economic pressure on some villages, which in turn causes young people to move to urban areas. (Wikipedia, the free encyclopedia accessed 2009)

Rural tourism takes many different forms and is pursued different reasons. There are developmental reasons to promote tourism as a growth pole such as for regeneration following agro-industrial collapse, or diversification of a remote marginal agricultural area into adventure tourism or cultural tourism (R.Okechet.el, 2012)

As stated by (A. Trukhachev, 2015), the rapid development of the global economy of last decades, coupled with the aggressive urbanization, puts rural communities into a difficulty. Rural tourism offers a possible solution to some of 
the problems associated with lost economic opportunities and population decline that accompany the waning of agriculture. Many governments and regional authorities have embraced rural tourism as an opportunity to bring new money into rural regions, stimulating growth, providing employment opportunities (K. Dashper, 2014).

\section{Backgroundof the Study Areas}

West Wollega is one of the 21 administrative zones of Oromia National Regional State. Administratively, the zone has 21 districts, of which 19 are rural districts and 2 are urban administrations. Gimbi town, which is located at a distance of $441 \mathrm{~km}$ from Finfinne, is the capital of the zone. NoleKabba and SayyooNole are two adjacent districts of west Wollega zone which are relatively located to the tip of the south of the zone to the north, north-west, and northeast of Ilu-Abba Bora zone, south-west of Yubdo district, in the south of Genji district and west of Haru

Figure 4. Map of study area

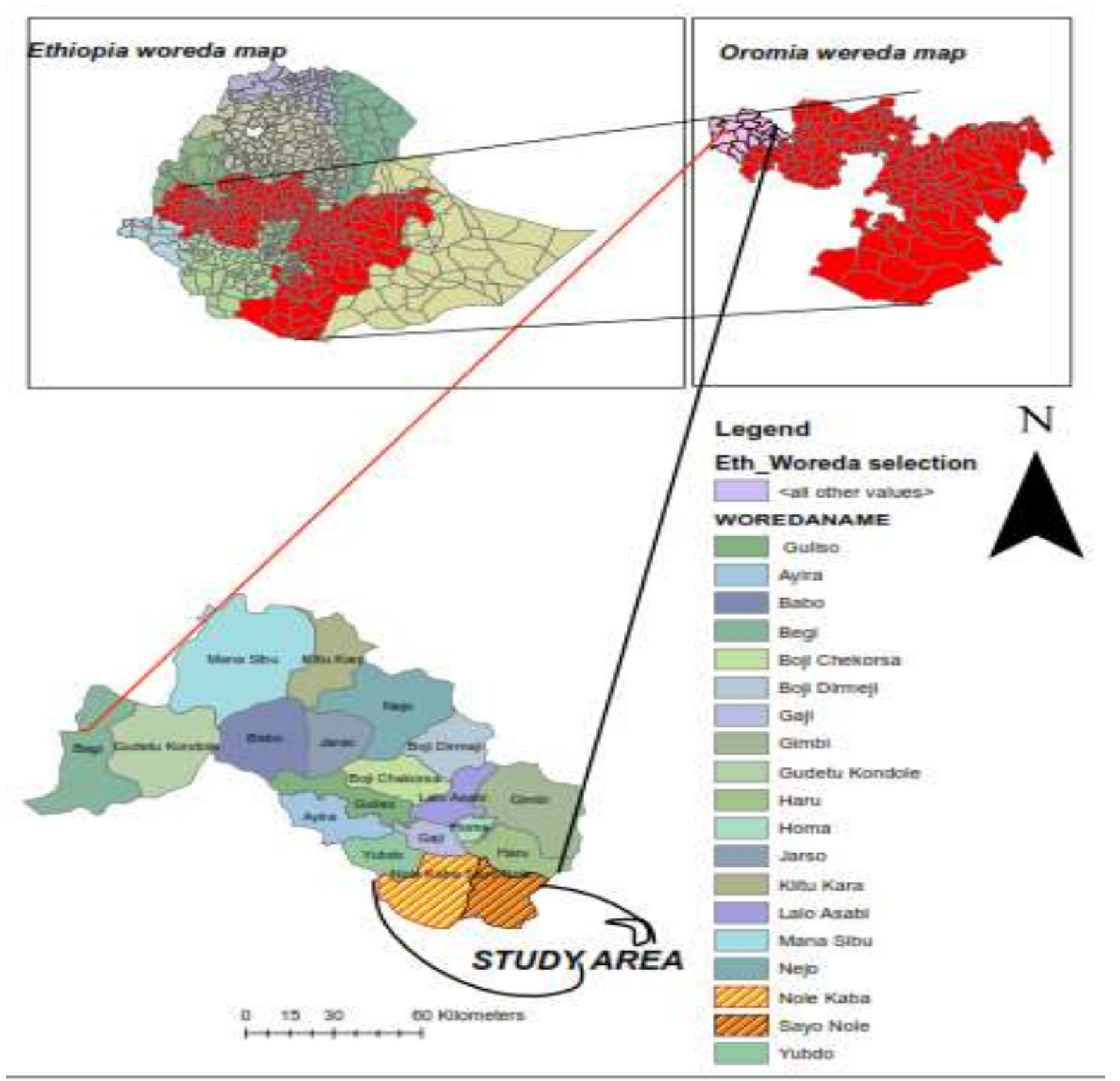

Source Computed from 2007 Gis data 


\section{DISCUSION}

\subsection{Current condition of tourism sector in the study area}

Table 4.1 Perception of Sample Population on Current Tourism Condition of the Study Area

\begin{tabular}{|l|l|l|l|l|l|l|}
\hline Arguments & Disagree & \multicolumn{2}{l|}{ Partially } \\
\cline { 2 - 6 } & Frequency & $\%$ & Fre, & $\%$ & $\begin{array}{l}\text { Fr } \\
\text { e. }\end{array}$ & $\%$ \\
\hline $\begin{array}{l}\text { Nature based and cultural tourism in the district are well } \\
\text { conserved and protected }\end{array}$ & 51 & 85 & 9 & 13 & & 0 \\
\hline The tourism sites are over populated area & 49 & 81.7 & 8 & & 3 & 5 \\
\hline $\begin{array}{l}\text { There is enough water supply, electricity, hotels, restaurants and } \\
\text { recreational areas to serve tourists }\end{array}$ & 51 & 85 & 7 & 11.7 & 2 & 3 \\
\hline $\begin{array}{l}\text { The tourism sites in the districts are well accessible for tourists } \\
\text { geographically }\end{array}$ & 9 & 15 & 21 & 35 & 30 & 50 \\
\hline $\begin{array}{l}\text { All tourism sites in the districts are governed and protected by } \\
\text { the state }\end{array}$ & 47 & 78 & 10 & 16.7 & 3 & 5 \\
\hline $\begin{array}{l}\text { Local community around the tourism sites have good } \\
\text { understanding about tourism }\end{array}$ & 36 & 60 & 19 & 31.7 & 5 & 8 \\
\hline $\begin{array}{l}\text { There is enough budgets allocated for tourism sector in the } \\
\text { district }\end{array}$ & 40 & 66.7 & 11 & 18 & 9 & 15 \\
\hline People who are employed within the sector are professional & 20 & 33 & 26 & 43 & 14 & 23 \\
\hline $\begin{array}{l}\text { There are/were projects from government and none government } \\
\text { bodies to develop tourism sector }\end{array}$ & 53 & 88 & 7 & 11.7 & - & 0 \\
\hline $\begin{array}{l}\text { The local community and the government office work together } \\
\text { actively to develop tourism sector in the district }\end{array}$ & 28 & 46.7 & 30 & 50 & 2 & 3 \\
\hline $\begin{array}{l}\text { There is/was promotion activities through local media and other } \\
\text { methods to develop tourism in the district }\end{array}$ & 46 & 76.7 & 11 & 18 & 3 & 5 \\
\hline
\end{tabular}

Source; field survey 2016

To be attractive and worthwhile for tourists, tourism sites should be protected and developed. Because it is very important, even vital source of income for many regions and countries. It's important in the Manila declaration on world tourism of 1918 as "an activity essential to the life of Nations because of its direct effect on social-cultural educational and economic sector of national society and on their international relations.

Tourism brings in a large amount of income to the regional and national economy. As stated in table 4.1,85\% of a sample survey, the tourism sites in the study area were not protected as suitable as attraction sites and the potential sites have a shortage of facilities, like road, water supply around destination and other accommodation facilities.

As indicated in table 4.1, the regional and local government gave little attention to the development of tourism potential in the study area. Because there was no enough budget for the sector, no promotion services, no training, and conservation practice for the local community, the absence of demarcation the tourism potential sites geographically from agricultural land. In addition, the sites are located within the agrarian society they were diminished and changed to the agricultural land by the local community. Because as it stated above the local community were not trained on the importance of tourism sites for development of local economy and its pillar for the livelihood of the rural community by reducing poverty.

In other ways, the people who are/were employed in tourism sector not directly professional to the sector. This is another problem observed in the study districts which contributes negatively to the development of the tourism service. Because there was no definite plane and strategies with in short and long period of tourism vision mission and objective of tourism potential sites development.

Other characteristics of tourism in the study area were no promotion of tourism sites by local government and people. Tourism industry is unlike any other, instead of product it is the selling of a place all the things it has to offer 
customer competing with the entire world every time you promote tourism in a given destination and this high level of computation demands a creative and unique approach to be successful, the site constantly put forth the best possible image of the destination.

\subsection{Destination Potentials}

(N. Popichite.t.1 2013) states that, the reason why tourists choose a destination is based on the extent of destinations' attractiveness and interestedness in influencing tourists' satisfaction. The assessment of destination potential helps to indicate and to rate the importance of existing destination resources in each region or province.

The study areahas diversity of destination potentials, natural and cultural tourism sites which were discussed in the next following pages

Study area tourism potential sites

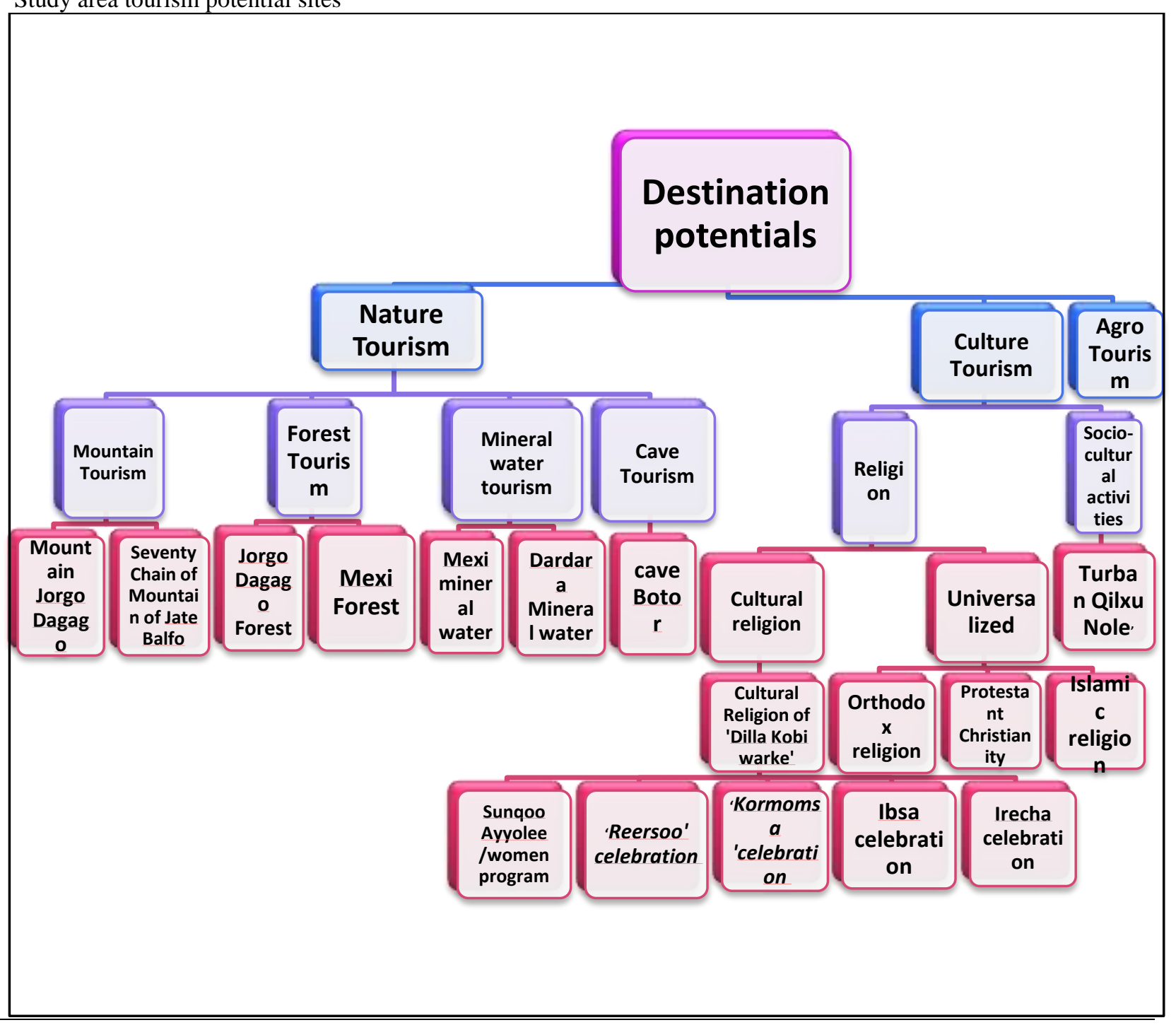

Source; developed by Author 2017

\subsubsection{Natural attraction sites/ nature tourism}

\subsubsection{Mountain tourism}

As stated by (UNEP, 2007), mountains have been a source of wonder and inspiration for human societies and cultures since time immemorial. Our fascination for these unique wilderness areas has been partly based on their 
remoteness and inaccessibility. Yet, today, the elements that attract people to mountains - clean air, diverse landscapes, rich biodiversity, and unique cultures - are under threat, partly because of poorly managed and nonsustainable tourism. Travel to mountain areas, which already attracts up to 20 percent of global tourism, is increasing rapidly.

According to Sustainable Mountain Development Series (2014), benefits to those mountain regions that were among the first to receive visitors, such as improvements to infrastructure for access and communication, the creation of jobs and businesses, and an opening to the outside world and experiences of otherness.

\subsection{Jorgo Dagago Mountain}

In accordance with the substances of the world, Jorgo mountain is a historical mountain associated with the Jorgo Dagago king of Nole Oromo people from which it acquired its name. This mountain founds at a distance of 509 kilometers from Addis Ababa, $68 \mathrm{Km}$ from Gimbi, west Wollega regulatory zone focus, and $18 \mathrm{~km}$ from Bube town NoleKaba locale (NoleKaba tourism part office 2009).

Figure 5 image of JorgoDagaago mountain

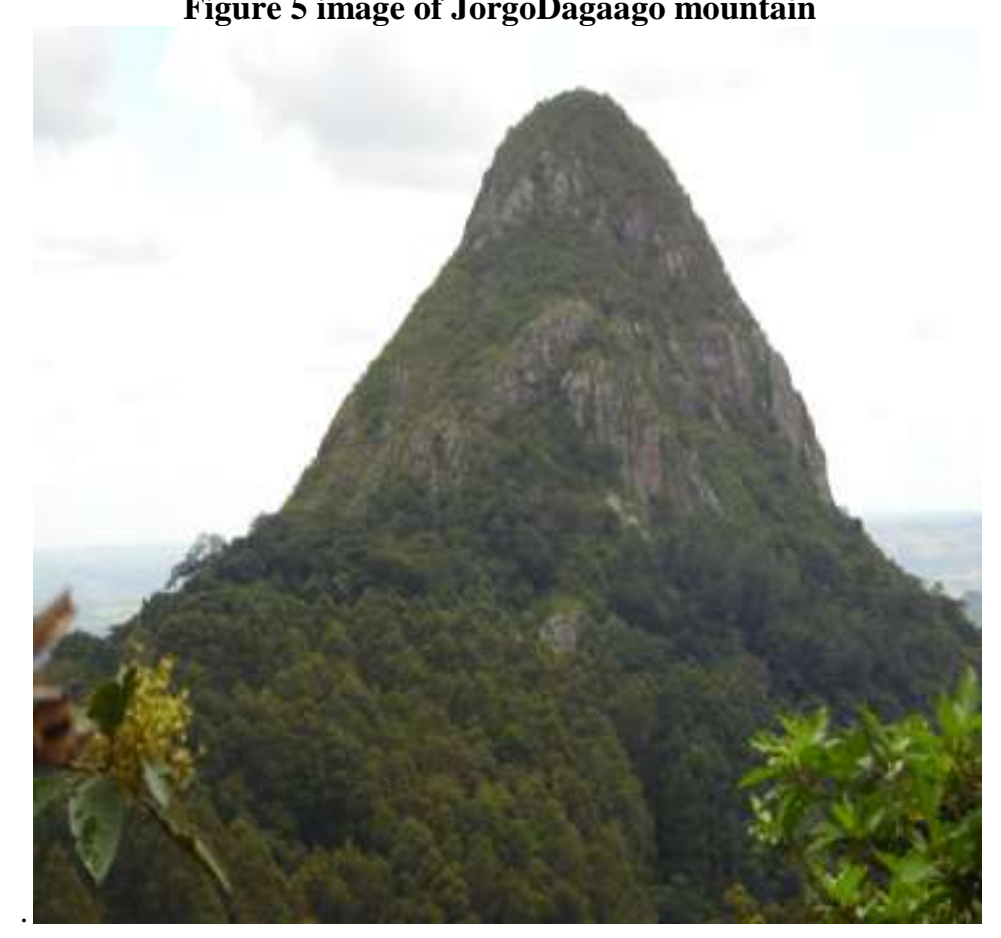

Source; field survey 2017

Survey 2017indicats that, Jorgo mountain has an altitude of $2258 \mathrm{~m}$ above sea level which is relatively the highest pick in the district. And this mountain site is surrounded by five kebeles (small local administrative division) namely Sayo kopi, SayoAsgory, SayoDalo and sayosilase. As information obtained from local elder's interview (2016), prior to the happening of the Christianity the mountain serves the nearby individuals as religious custom regions for a long period of time. This demonstrates how much social movement of individuals tied to nature, particularly normally one of a compassionate domain around their area. The mountain has social interest for appealing, calm, protected and common looking spaces for recreation, accessible for tourists, landscape protection, quality environment and forest sounded area.

Therefore, Jorgo mountain is environmentally very attractive due to its location within a forest, its historical prospect in connection with ancient local governors, its highest pick from the local natural landscape and it is home to diversity of wild animals like lion, ape, gorilla, monkey etc. due to its environmental suitability and natural 
endowment it can be appropriate area to be park or zoo. Therefore, JorgoDagago mountain environmental area is awarded historical, natural and cultural attractive potential site in the study area.

\subsection{Seventy Chain of Mountain of JateBalfo}

The seventy chain of mountain locally known as 'GaaraTorbatama' located in the west Wollega zone SayoNole district at specific place Known as BantiSamaro and Abbichukebeles. The mountains named by the local king JateBalfo, who discovered and lived there for long period of time. These chain of mountains are cover large area with $16 \mathrm{~km}$ distant to reach from one end to another end of the chain.

As it was obtained from local elders during interview 2017, throughout ancient time there was no settlement and there was no name assigned to these chain of mountains. But the person Known as JateBalfo came to the area by crossing Gibe River for the sake of hunting. In Oromo Culture hunting big animals give high admiration and recognition of protagonists in the social value, which were the reason for the person to travel a long distance to kill buffalo in the discovered area. The local people witnessed their myth that this person gave the name "GaraTorbatama" literary known as seventy mountain chains for this area based on the number of streams of mineral water located around the chain of the mountain. (interview, 2017).

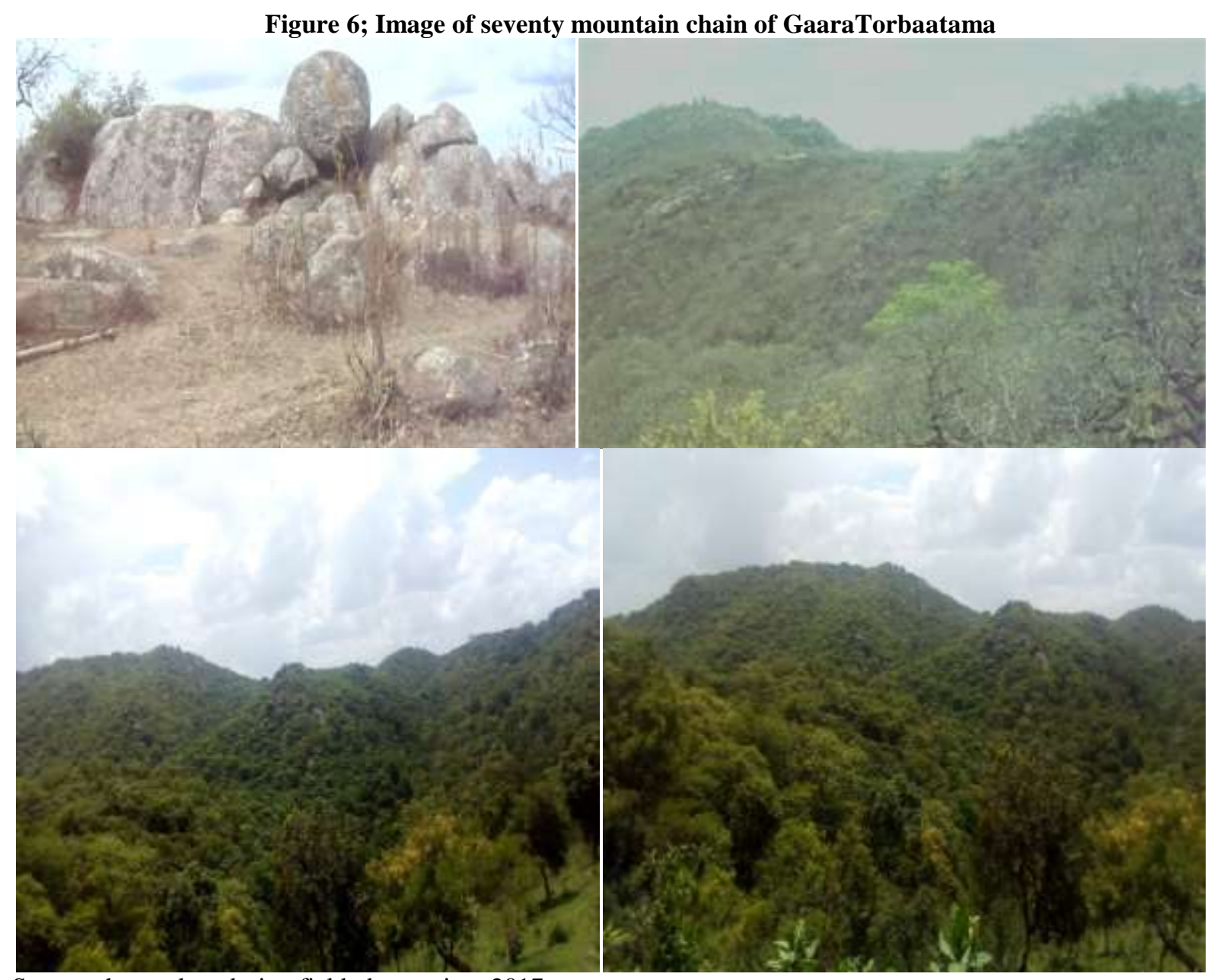

Source;photo taken during field observation, 2017

The topography of these mountains are ups and downs with a different altitude of the mountain chain and it covers approximately 665.5 hectors of the surface of the earth. These chain of the mountain are endowed with natural resources like different kinds of animals and plants, unlike other mountain areas it is the evergreen environment, 
large areal coverage bounded by very beautiful 'Meexii' (palm tree) green forest and environmentally diversified landscape for the attraction of tourists.

\subsubsection{Natural Forest as Tourism site}

Forests, woodlands, and trees provide what may be termed amenity services. These attract people to visit forests specifically, and to countryside areas more generally, where the presence of trees and woodland contributes to the amenity value of the landscape. These visits necessarily involve expenditure which provides income to local businesses, supports employment and economic output. A proportion of these visits can be classified as 'tourism' visits. Understanding the influence that forests and forestry practices have on tourism visits and associated expenditures is important for those bodies charged with their management (Hill et.el, 2003)

(A.Ahtikoskiet.el, 2011) stated that, Forests in general, provide many functions, producing, e.g., recreational services, timber, biodiversity and carbon sinks. Decisions concerning the management of forests unavoidably involve trade-offs between these alternative uses. Forested landscapes provide policymakers as well as practitioner's multiple management objectives that include the production of an array of both marketed goods and non-marketed ecosystem services, forest externalities

\subsection{Jorgo Dagago Forest}

According to district tourism office (2017), JorgoDagago forest is located between two zones of Oromia region, IluAbbabora, and west Wollega. In Illu-Abbabora the forest covers some areas of Alge district and in west WollegaNoleKaba district. this forest is located 500km from Addis Ababa 59km from Gimbi and $9 \mathrm{~km}$ from NoleKaba district administrative center, Bube. JorgoDagago forest surrounding the highest mountain Dagago and it was evergreen, very attractive topography and suitable climatic condition. the forest is a mixture of natural and manmade trees. As stated by informants during the survey (2017) there were trees assumed to be more 300 years old, like Pouteriaadolfifriedrici, locally Known as Kararo

There are different wild animals within the forest like buffalo, pig, gorilla, apps, Lampard, lion and the others are/were living in the forest. Therefore, even the forest can serve as parks if it protected and managed. Dagago forest covers 8983 (including AlakuDambiforest) hectors in West Wollega, NoleKaba district, 11,195 hectors in IlluAbbabora zone. Based on the above indicated diversified natural resources, the forest has a high potential for tourist attraction site if it is developed and protected for the suitability of tourism site.

\section{Figure 7; Maps of Jorgo Dagaago forest}

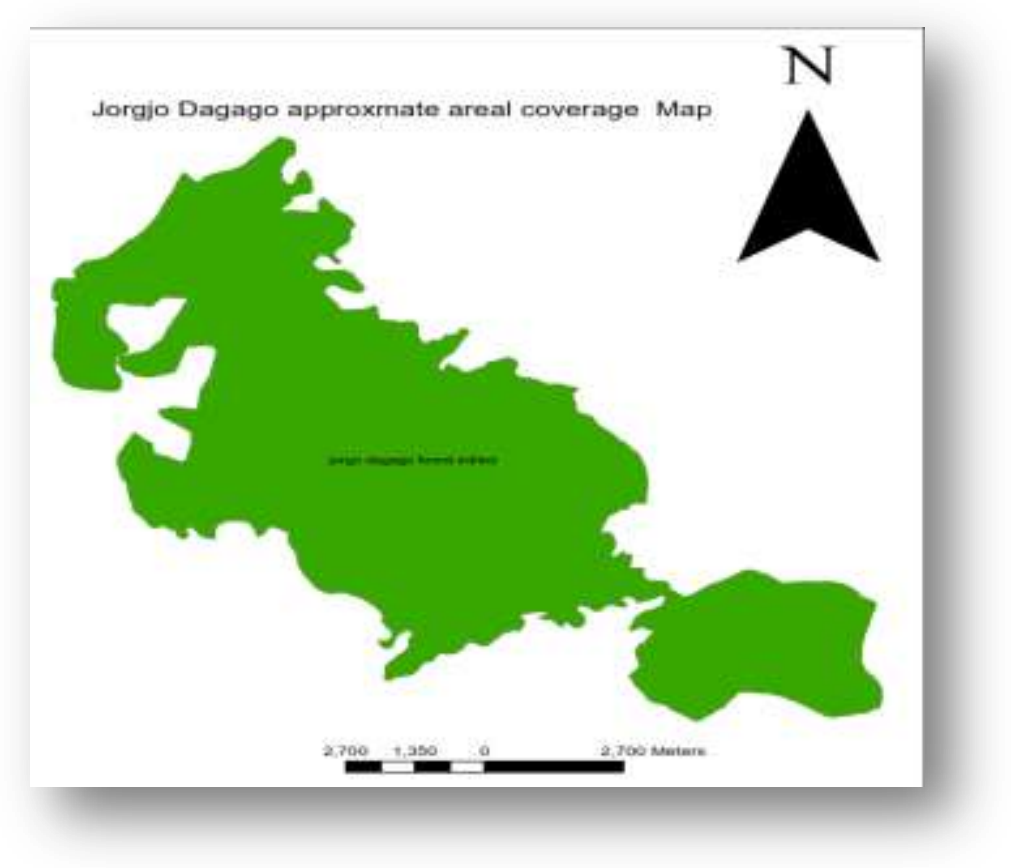

Source; Computed from google earth 2017 

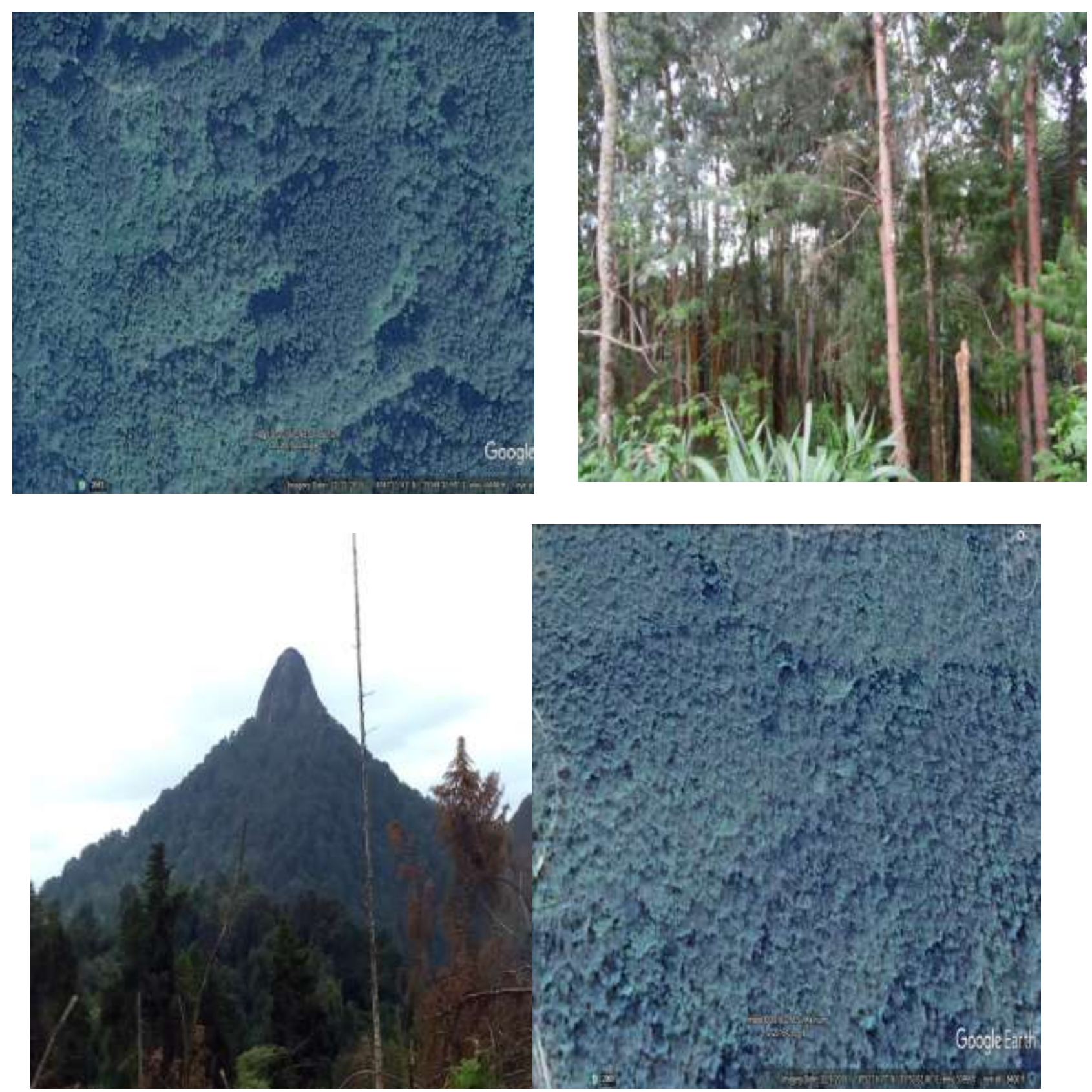

Source; photo taken during field observation, 2017

\subsection{Mexi Forest}

As stated by Sayo district tourism office (2017), Mexi forest is located at a distance of $103 \mathrm{~km}$ from west Wollega administrative center Gimbi and $30 \mathrm{~km}$ from Debeso town, sayyooNole administrative center. As is indicated by the image below Mexi forest is found between two zones of Oromia region, west Wollega, and Illu-Abbabora, which delineated by MeexiRiver. This forest is gifted of diversified natural resources, such as MexiRiver which does not show significant fluctuation seasonally and serving as a boundary between Illu-Abbabora and west Wollega zones, Mexi mineral water, and different wild animals within the forest like the lion, buffalo leopard, monkey, hippopotamus, crocodile, and others. Therefore, these all natural attractive resources at some place have a high potential for tourism magnetism it has appropriateness area to be zoo and park if they developed and protected for the suitability of tourism attraction site. 


\section{Figure 8, Google image of Mexi forest}

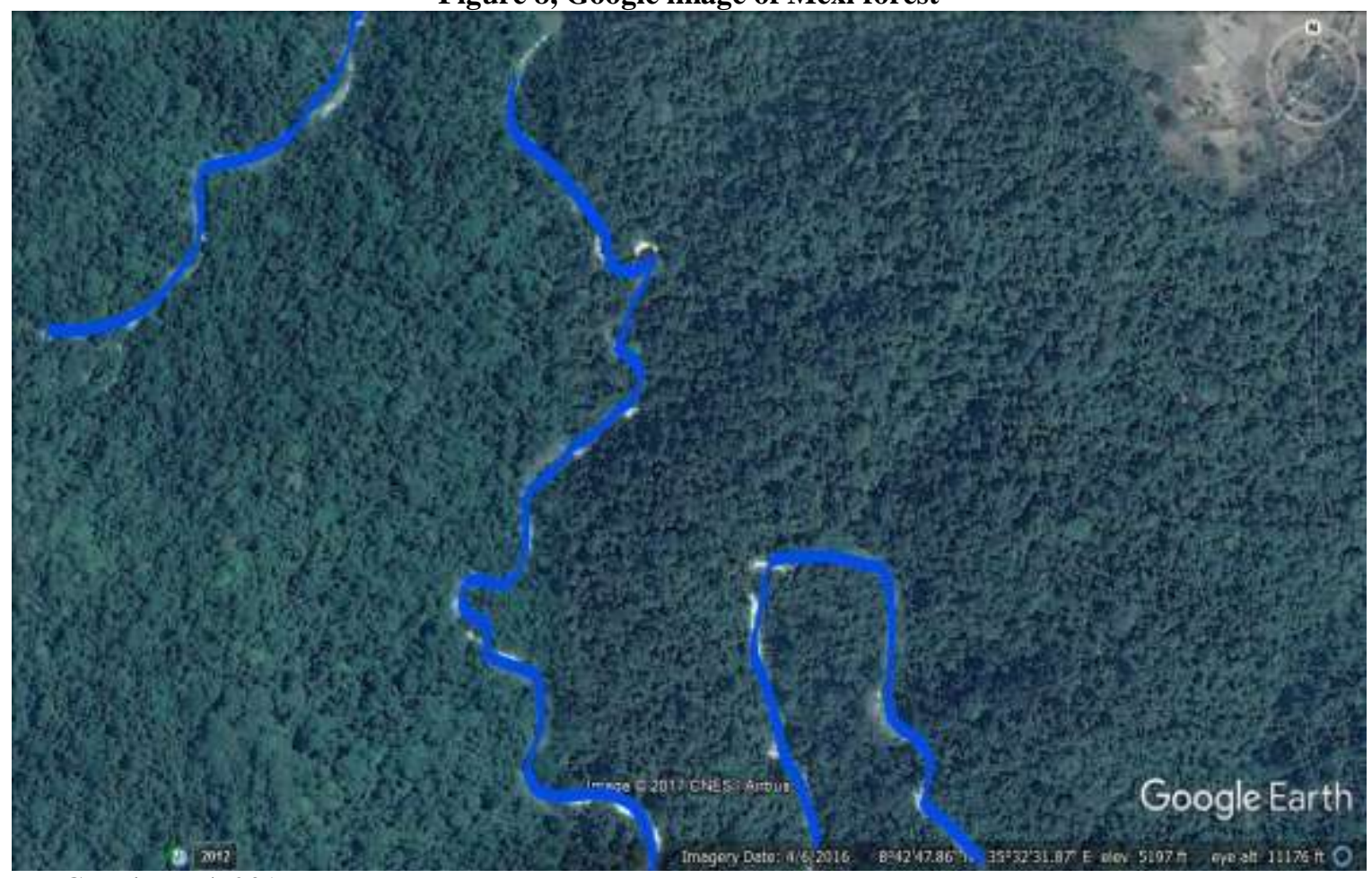

Source; Google earth 2017

\subsubsection{Mineral Water as Tourism Site}

Mineral water is water from a mineral spring that contains various minerals, such as salts and sulfur compounds. Mineral water may be gassy or "sparkling" due to contained gases. Traditionally, mineral waters were used or consumed at their spring sources, often referred to as "taking the waters" or "taking the cure," at places such as spas, baths, or wells. The term spa was used for a place where the water was consumed and bathed in; bath where the water was used primarily for bathing, therapeutics, or recreation; and well where the water was to be consumed. Today, it is far more common for mineral water to be bottled at the source for distributed consumption. Travelling to the mineral water site for direct access to the water is now uncommon, and in many cases not possible because of exclusive commercial ownership rights. There are more than 3,000 brands of mineral water commercially available worldwide (Wikipedia, the free encyclopedia 2016).

\subsection{Mexi mineral water}

The Mexi potential site of tourism is located in West Wollega Zone SayyooNole district. information obtained from (interview 2017) indicates that, the mineral water serving the local people for different purposes among these for cattle drinking, for medicine and for washing clothes. The mineral water not serving only society around the area but also for other zones like parts of Illu-Ababora and some woredas of QelemWolega in ancient time. According to the interviews 2017 the two local kings JorgoDagago and JateBalfo fought over this mineral resources but informally it was said that a women lived around the area was cause for peace between them through negotiation, while she haired their quarrel she contributed arguments for their agreement by saying

HururuYaamucaakoo (Calm down my son)

Iluufardihingufatu(No obstacle for riding horse in Illu)

Nolefardihingufatu(No obstacle for riding horse in Nole)

Dhoheelaftishingubatu (No earth explosion and burn)

Hora JechuunMexumakanlaftibiqilche (Mineral water means Mexi from earth part)

Gowan kana hinhubatu(But the fool not understand the truth)

Literally, the message of a womansong was to indicate the earth has a long history and it can live forever. Dispute the fact, people do not understand their stay for short period of time on the earth while they quarrel on the resources of the earth. When the lady saying this song the people arbitrating these two kings heard hersong and they 
understood the message that convey every resources on the earth belongs to the God. then they realized the owner of all territory was not the kings but the God. Therefore, they came to negotiation by the mediation of local elders. This indicates that the mineral water has a strong history with local people in terms of its function.

Figure; 9Image of Maxi mineral water
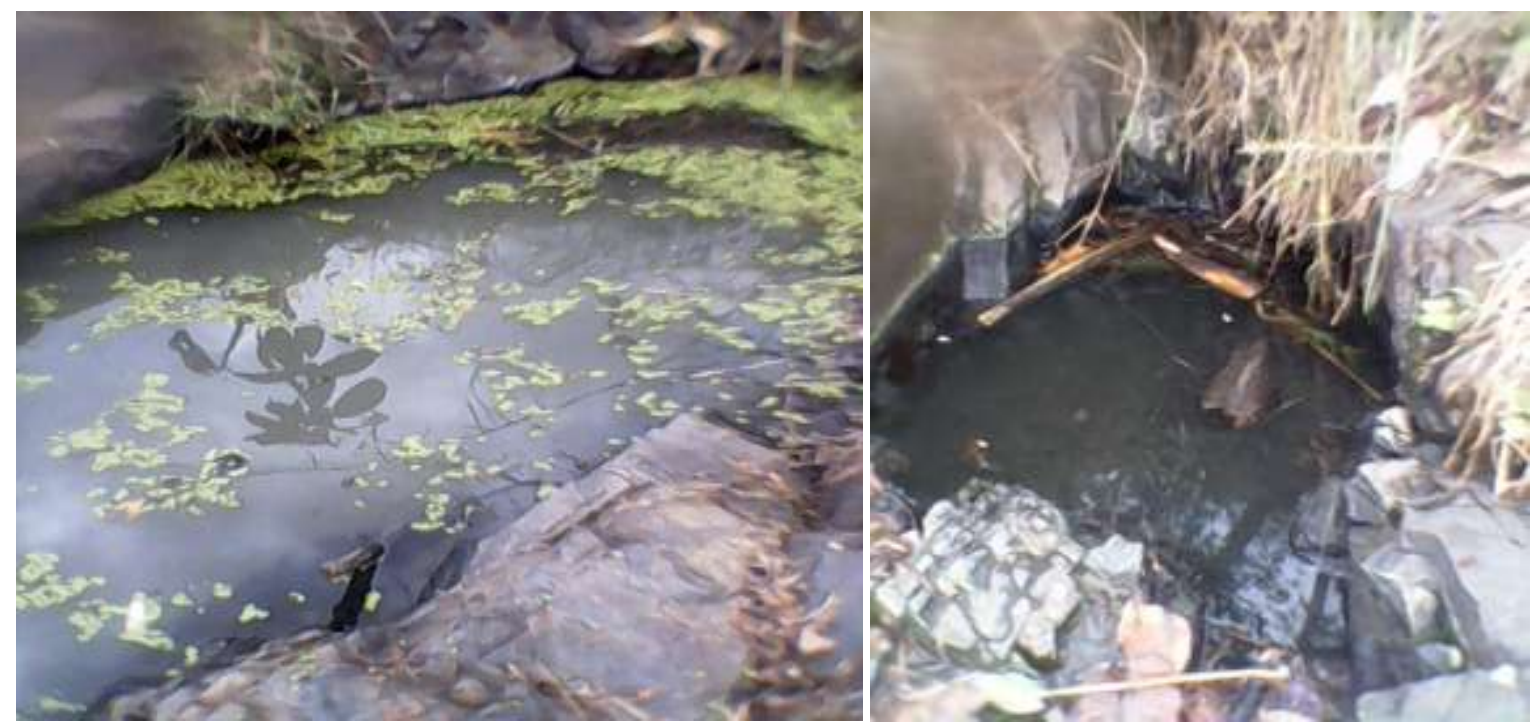

Source;photo taken during field observation, 2017

The numbers of wells of mineral water were around seventy-seven in number. The local elder's countersigned that, even the name of seventeen chains of mountains were named basically from these mineral waters. But due to climatic change and mishandling theses mineral water walls mostly dried out and only left with three pits their local names were Gala Robe, Gamula, and Gola Mexi.

According to interview (2017), there are different wild animals around these mineral water which were drinking the water daily like a lion, hippopotamus, buffalo, leopard etc..... The perception of local people indicated that if the government give focus on these resources it can be tourism site. Generally, due to its historical prospect and environmental attraction which was surrounded by large forest namely Mexi and its importance for local and national development, it has high potential to be advanced as to tourism site.

\subsection{Dardara Mineral water}

Dardara mineral water found in West Wollega zone, SayyoNolle district at a distance of 499km from Addis Abeba, $58 \mathrm{~km}$ from Gimbi and $8 \mathrm{~km}$ from the administrative center of NoleKabadistrict, Bube town. Traditionally, the Oromo people have a long history in using mineral water for their cattle what they call "hora". Likewise, the NoleKabba Oromo uses this mineral water for long period of time. Based on document obtained from NoleKabba district office 2017 to indicate the significance of the mineral water to them by saying

\section{'BeeginGafarsaankooraa'(Begi isproud of their buffalo) \\ 'AnfiloonBunaankooraa'(Anfilo isproud of their coffee ) \\ 'GimbiinGabaadhaankooraa'(Gimbi isproud of their market) \\ 'Yubdoonwarqeedhaankooraa'(Youbdo isproud of their gold) \\ 'MandiinDhadhadhaankooraa'(Mandiisproud of their butter) \\ 'NooleenDardarankooraa' (Noleis proud of Dardaramenial water) \\ Ani maalitankoorahiyyeesimatatoraa( I'm poor, thus have nothing to proud)}

The above traditional song at different social occasions by individuals was to indicate how much Dardara mineral water have a strong significance for local people. This mineral water serving the local people across the district for their cattle as was shown in the figure 10 which was taken during the survey when they flock with their cattle. Therefore, the people's activities tied with their culture to use this mineral water and have a high potential for the attraction of tourists to the area. The areal coverage of this mineral water is approximately $300 \mathrm{~m}^{2}$ with the $15 \mathrm{~m}$ 
depth. It has nine sources or streams, such as Eala, Amuna, Alga, Nya'a, Siba, Awana, Tufa dacha, Ganji, and Debeso.

Dardara mineral water wasn't occasional because of its area inside the woodland arrive. As indicated by the accept of the neighborhood individuals, this mineral water is vital to secure and safeguard them and their creature from various illnesses, a serious proliferation of their creatures. For the most part, the specialist trusts that past its high potential for tourism fascination, these mineral water needs more distant research standardized and institutionalized advantage for the national and neighborhood individuals.

Figure 10; Images of Dardara Mineral water
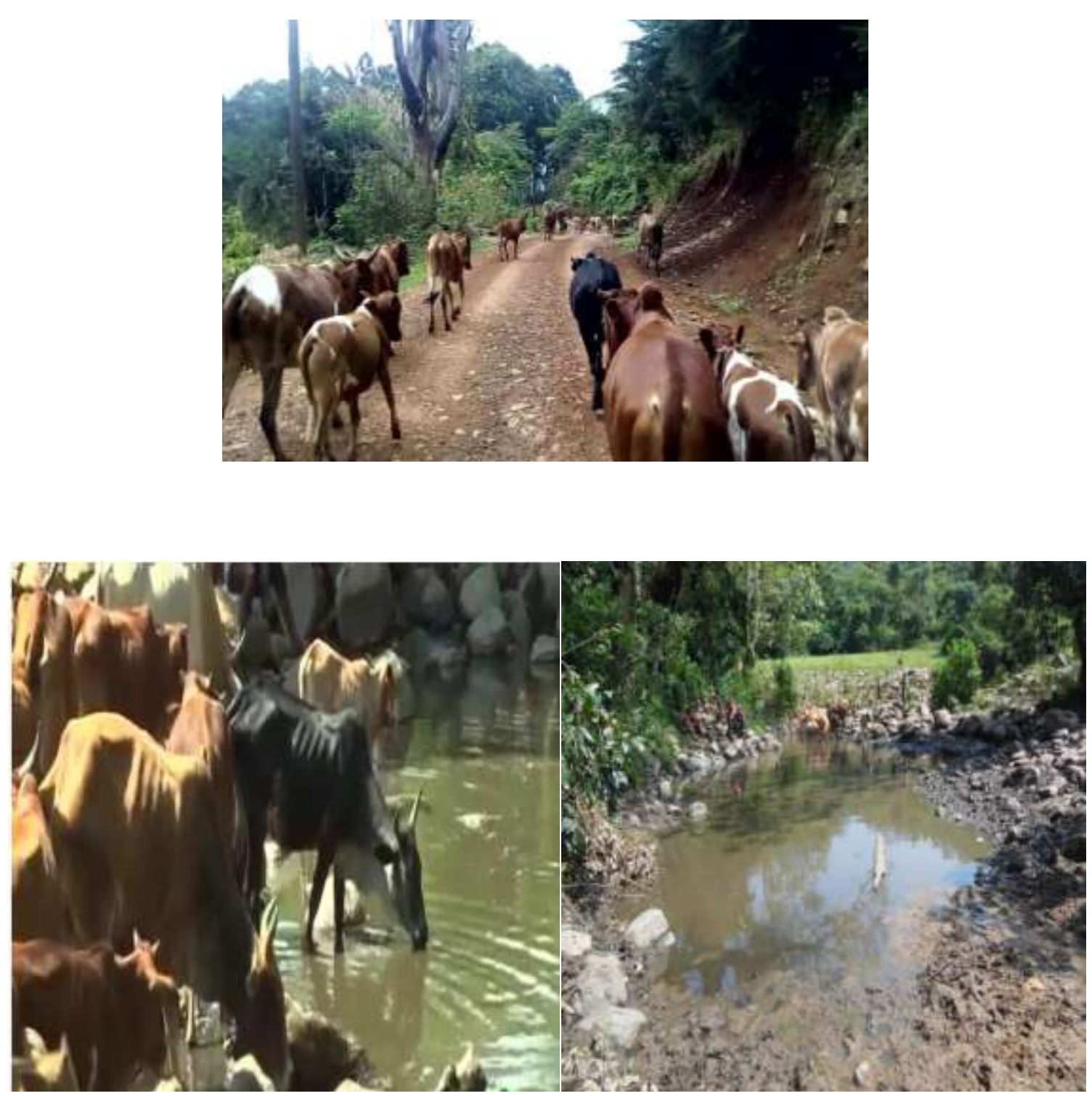

Source; photo taken during field observation, 2017 


\subsubsection{Cave Tourism}

According to (EDP 2014), Caves are part of nature tourism, or "ecotourism", that is capable of attracting tourists. Caves are important to the tourism industry because it develops rapidly in developing countries, where hundreds of caves every year are developed for that purpose. It could be said that caves form a complex natural resource in the large-scale tourism trade of a particular country. There are more than 5,000 tourist-friendly caves around the world currently, with 10 of them being significant caves. Cave tourism successfully pulls approximately 250 million tourists every year with an estimated expenditure of USD2 billion, apart from providing employment to 200,000 people and generating a total household income of USD100 million per year

\section{Figure 11, image of cave Botor}

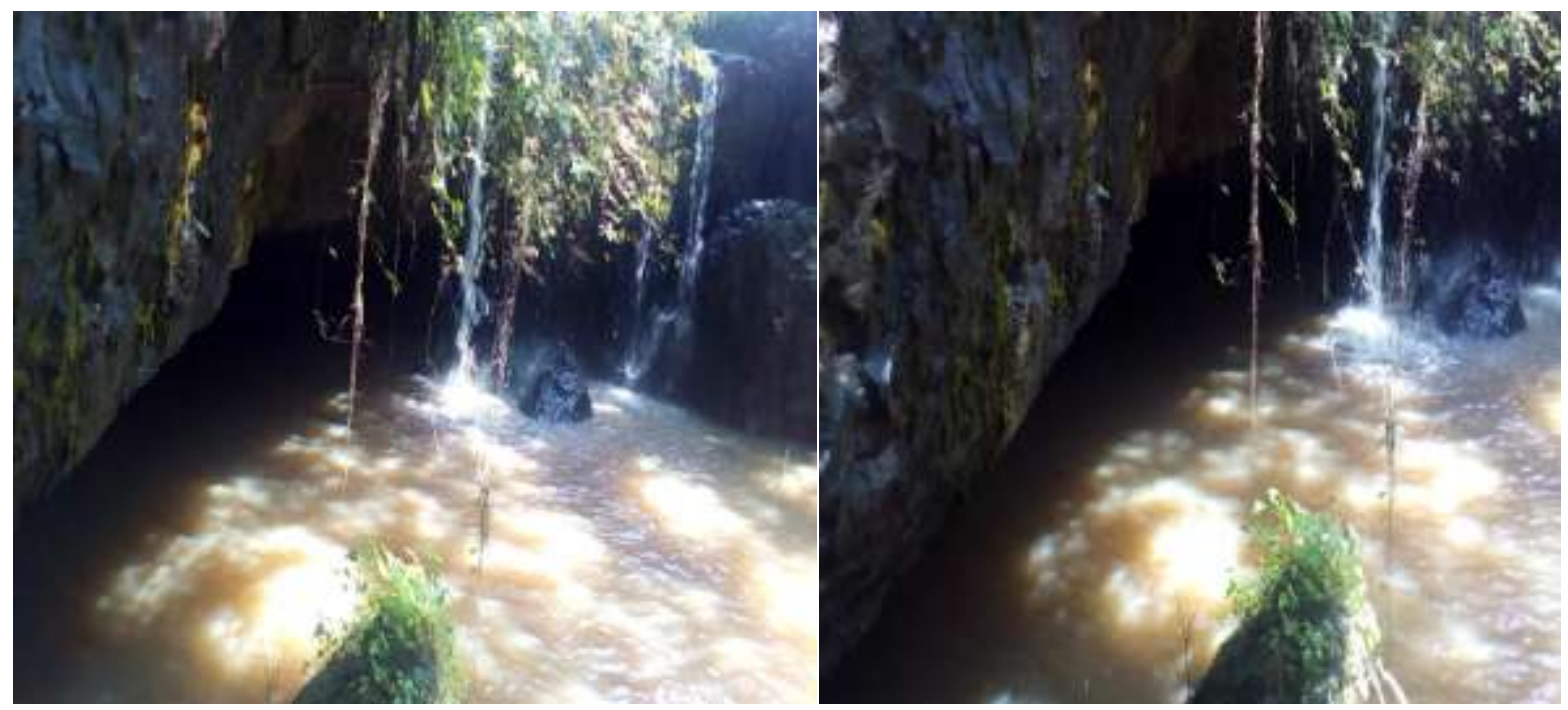

Source;photo taken during field observation, 2017

This cave is found in west wollega zone in SeyyoNale district with $518 \mathrm{~km}$ from Addis Ababa $77 \mathrm{~km}$ from Gimbi and $9 \mathrm{~km}$ from district center Debeso. the cave was surrounded by green forest and very attractive waterfall. As is shown in the figure 11, there is a waterfall at the top of the cave but the water not flows to the inside of the cave. The cave was dry, very wide and long. The local people supposed, approximately they discovered the cave up to $50 \mathrm{~m}$ by traveling through it. The cave also the home of wild animals like hyena, python, fox and the others.

Therefore, this research invites the speleologist to study the caves farther feature, structure, physical properties, history life forms, and the process by which they formed. But for this research due to its environmental attractiveness unique landform, it can serve as a tourist potential site.

\section{Conclusion and recommendation}

To conclude; the study area is/was endowed with high potential tourist attraction sites, including quality and preserved environment, diversified cultural and natural tourist attraction areas, good climatic condition and a good will of the local community for local tourism development. But there was no progress of tourism development due to different challenges in the study area. These challenges have no attention from local and regional government to make tourism one way of poverty alleviation mechanism within the rural economic development.

The challenges of tourism development identified by the research were a shortage of infrastructure, shortage of promotion services, expansion of agricultural land to the potential sites, shortage of resources, tourism market, the problem of implementation of policy and geographical inaccessibility. Based on these challenges the research developed scenarios on future prospects of tourism development as a service industry. Accordingly, active participation of the local community, developing communication media groups, the active concern of regional and local government, the contribution of non-governmental organization and engagement of religious institutions in 
tourism development seen as none alternative option to solve the problems within the future development of tourism.

\section{Recommendation}

Depending on the findings of the study the authorrecommends the following that has to be taken by concerning bodies. This is to mean that what does the local, regional and the community needs to know for the better design and development of tourism at the study area.

* The regional, as well as local government, have to formulate appropriate policy and control mechanism for the policy development and implementation.

* The local authorities have to give training and making active participant of tourism community in the sector development process

* There should be cooperation of natural resource management department, agricultural sector with the tourism office in order to conserve natural resources and develop tourism potential sites through protection.

* There should be tourism promotion services by regional and national media, by local people and even by government workers of the districts. To do so the government have to strengthen the regional and national media to have programs concerning the study area tourism potential in particular and the western part of the nation in general

* The other main problem of tourism development at the study area was the shortage of infrastructure. Therefore, to promote tourism potential sites the government should give unusual focus on developing infrastructures within rural community

\section{References}

[1]. A. Kauffmann 2008. Challenges and future prospective tourism development in centeralrefitvalley, Ethiopia

[2]. Alexander Trukhachev2015, Methodology for Evaluating the Rural Tourism Potentials: A Tool to Ensure Sustainable Development of Rural Settlements

[3]. Alina Zajadacz Adam Mickiewicz University 2014, in Poznań Faculty of Geographical and Geological Science Department of Tourism and Recreation alina@amu.edu.pl Accessibility of Tourism Space from A Geographical Perspect

[4]. AnssiAhtikoski and et.el 2011, Potential Trade-Offs Between Nature-Based Tourism and Forestry, a Case Study in Northern Finland

[5]. AnssiAhtikoski,,SeijaTuulentie , Ville Hallikainen , VesaNivala , EeroVatanen , LiisaTyrväinen and HannuSalminen 2011, Potential Trade-Offs Between Nature-Based Tourism and Forestry, a Case Study in Northern Finland

[6]. ASC Info sheet 3 / 2008; Africa Studies Center tourism in Africa http://www.ascleiden.nl/Pdf/Infosheet3engels.pdf

[7]. ErmiasKifle 2014, Challenges of Religious Tourism Development: The Case of Gishen Mariam, Ethiopia Hawassa University Wondo Genet College of Forestry and Natural Resources, School of Wildlife and Ecotourism, Ethiopia

[8]. Federal Ministry ofCulture and Tourism 2009-2012, Tourism Statistics No. 10Bulletin Addis, Ababa Ethiopia

[9]. GloPent 2016, European Research Network on Global Pentecostalism Brief History of Pentecostalism in Ethiopia https://www.glopent.net/Members/jhaustein/ethiopia/brief-history-of-pentecostalism-in-ethiopia/

[10]. Hill, G and et.el 2003, Forests' Role in Tourism: Phase 2 SUMMARY REPORT - FINAL for the Forestry Group (Economics \& Statistics) of the Forestry Commission The Macaulay Institute, University of Gloucestershire, BioSS

[11]. http://www.selamta.net/ethiopian\%20muslims\%20history.htm

[12]. ICLRT (1981)- the International Conference on Leisure-Recreation-Tourism tourism and travil agency management Cambridge cutorial college

[13]. Josephine Wawira 2016, The Role of NGOs in Africa's Tourism Consultant at Jumia Travel

[14]. Karar, 2010, Impact of Pilgrimage Tourism at Haridwar. Anthropologist

[15]. Katherine Dashper 2014, Rural Tourism: An International Perspective Cambridge Scholars Publishing 12 Back Chapman Street, Newcastle upon Tyne, NE6 2XX, UK British Library Cataloguing in Publication Data A catalogue record for this book is available from the British Library

[16]. Local authority supporting tourism 2017, Role of Local Government in Tourism Ireland http://www.lgma.ie/sites/default/files/newsfiles/fo1_role_of_local_government_in_tourism.pdf accessed in 2017

[17]. Malta Tourism Digest- www.mtadigest.com.mt world tourism organization 2012

[18]. MeseretGetahun 2011, The Impact of Service Trade On the Economic Growth of Ethiopia: The Case of Tourism, School of Graduate Studies of Addis Ababa University)

[19]. Michael Muganda, Agnes Sirima1 and Peter Marwa Ezra 2013, The Role of Local Communities in Tourism Development: Grassroots Perspectives from Tanzania Department of Wildlife Management, Sokoine University of Agriculture, Morogoro Tanzania, P.O. Box 3073 Morogoro, Tanzania J Hum Ecol, 41(1): 53-66 
[20]. Nicole Vaugeois 1990). Tourism in developing countries: refining a useful tool for economic development

[21]. NongluckPopichit and e.t.1 2013, A Survey of Destination Potential, Tourism Activities and Future Travelling Intention towards Tourism along the Rivers in PhraNakhon Si Ayutthaya Province

[22]. NongluckPopichit and e.t.1 2013, A Survey of Destination Potential, Tourism Activities and Future Travelling Intention towards Tourism along the Rivers in PhraNakhon Si Ayutthaya Province International Journal of Business and Social Science Vol. 4 No. 7; July 2013

[23]. P.C.Sinha(-),tourism impact assessment, internal encyclopaedia of tourism management series tourism impact assessment

[24]. Profit tourism in east Africa and in the Indian Ocean (regional summary) obtained on line 2012 .http://www.bkconseil.com/espaceinformation/documentation/elements/tourism_in_eaio_regional_study.pdf

[25]. Rinschede, G. 1992. Form of Religious Tourism. Annals of Tourism Research

[26]. Robert Christie Mill 2010.Tourism the International Business, The Global Text Project is funded by the Jacobs Foundation, Zurich, Switzerland

[27]. RoselyneOkeche.t.1 2012, Rural Tourism as A Sustainable Development Alternative: An Analysis with Special Reference to Luanda, Kenya

[28]. Selamta 2017, EthiopianMuslims History,I

[29]. Sonja Jovanović2016, Infrastructureas Important Determinant of Tourism Development in The Countries of Southeast Europe Ecoforum [Volume 5, Issue 1 (8), 2016]

[30]. Tooman, A.L. (1997). "Tourism and development" Journal of Travel Research., v. 35

[31]. Tourism in east africa and in the indian ocean (regional summary) http://www.bkconseil.com/espaceinformation/documentation/elements/tourism_in_eaio_regional_study.pdf

[32]. UNEP 2007, Tourism and Mountains a Practical Guide to Managing the Environmental and Social Impacts of Mountain Tours

[33]. UNWTO 2016, European network tourism), Manual on Accessible Tourism for All: Principles, Tools and Best Practices Publications Module V: Best Practices in Accessible Tourism

[34]. UNWTO 2016, Manual on Accessible Tourism for All: Principles, Tools and Best Practices Module V: Best Practices in Accessible Tourism

[35]. Wikipedia the free encyclopedia) en-wikipeda.org/wiki/tourism-in-Ethiopia

[36]. Wikipedia, the free encyclopedia 2014, https://en.wikipedia.org/wiki/Nole_Kaba

[37]. Wikipedia, the free encyclopedia 2017, Christianity in Ethiopia. https://en.wikipedia.org/wiki/Christianity_in_Ethiopia\#Christian_Roots

[38]. WTO 2001, Tourism Challenges in the 21st Century - Human Resource Development in Asia and the Pacific (English version)I

[39]. WTTC 2017, Travel \& Tourism Global Economic Impact \& Issues 2017

[40]. YabibalMulualemWalle (2010). Tourist Flows and Its Determinants in Ethiopia, Ethiopian Development Research Institute Addis Ababa, Ethiopia

[41]. Encyclopedia of Life Support Systems (EOLSS); _THE SUSTAINABLE DEVELOPMENT OF TOURISM IN AFRICA,Penelope Urquhart Vol. II South Africa, eolss.net/Sample-Chapters/C16/E1-48-50.pdf 